NOTAS

\title{
INSULARIDAD Y EXILIO DE LOS INTELECTUALES CUBANOS Rafael Rojas*
}

I. Muerte diacrónica de las culturas

\section{$\mathbf{E}$} n Occidente es posible la desaparición de las culturas nacionales. Este es el sombrío mensaje que dejaron Oswald Spengler y Arnold Toynbee en su historiografía morfológica. Y la historia europea más de un ejemplo: la cultura flamenca del siglo XVI, la vienesa de finales del siglo pasado y la soviética de los años 70, han perdido para siempre su espacio y trascendencia temporal. Pero también es posible, y no sólo en Occidente, que al interior de una

* El Colegio de México. ...era cubano aun antes de existir Cuba como nación. Ese oficio del siglo paradójicamente lo aprendió en el exilio.

\section{Guillermo Cabrera Infante}

tradición nacional desaparezcan las culturas diacrónicas que cifran el pasado de un país. Ese es el caso de Cuba, donde al parecer se cierran herméticamente los ciclos de la nación y se rearticula con facilidad el patrimonio simbólico.

En la trayectoria cubana unas culturas se esfuman sin dejar rastro, dando paso a otras que se articulan desde frágiles herencias. El imaginario criollo del siglo XVIII desapareció en el patriciado cubano del siglo XIX. Por su parte la simbología patricia se descontinuó durante la primera experiencia post-colonial de 1902 a 1933. Luego, la sociabilidad clientelar, la práctica del 
NOTAS

choteo y el discurso de la decadencia fueron desplazados por la retórica de la renovación cívica, las vanguardias artísticas y la espiritualidad nacional. A una Nación en busca de un Estado le siguió entonces un Estado en busca de una Sociedad. Esta cultura republicana, que había cristalizado en la Constitución de 1940, fue interrumpida bruscamente con el golpe militar de Fulgencio Batista en 1952. Hacia finales de la década, la Revolución pareció rearticularla en virtud de resolver históricamente su propia ruptura, pero ya para 1961 otro orden la cancelaba sin inercia. Tras la indefinición inaugural de la ideología revolucionaria predominó cierta sensibilidad guevarista, que después sería marginada por el sistema filosoviético en los años 70 . Este sobrevivió hasta finales de la pasada década, cuando por fin se origina la cultura crítica de la transición cubana actual. Así, la historia insular ha devenido en una sucesión de tensos escenarios culturales que se excluyen mutuamente.

El deceso diacrónico de las culturas en Cuba da la impresión de estar ante un país donde la densidad de la historia es casi nula. En efecto, se trata de una nacionalidad muy joven, cuya integración étnica y cultural no se inició hasta mediados del siglo XIX. Allí no se fijaron estructuras perdurables del antiguo régimen colonial: como las corporaciones militares y eclesiásticas, los pueblos de indios, los tribunales, la Inquisición, las audiencias y el complejo sistema de castas. En Cuba la cultura criolla fue menos sólida y el mestizaje más acelerado que, en los virreinatos latinoamericanos. La raíz africana, más proclive al sincretismo que la indígena, introdujo una lógica de enlaces y traducciones sumamente peligrosas para la estabilidad del orden colonial. En vez de una jerarquía estamentaria, con todo el metarrelato jurídico que ella acarrea, se dio el difícil engranaje de plantación entre la esclavitud racial y la industria azucarera, entre la mística antiliberal y el mercado atlántico. Por eso se puede afirmar que la excepcionalidad histórica de Cuba, más que radicar en la tardía separación de España, reside en la ausencia de un auténtico ancien régime, es decir, en la falta de un verdadero pasado holístico sobre el cual imponer la sociedad moderna. ${ }^{1}$

Claro, el hecho de que el clásico orden corporativo español haya fracasado en Cuba no supone la inexistencia de un pasado colonial. Así como la imagen de un devenir discontinuo y quebrado no implica el trauma de un pueblo sin historia y una nación sin identidad. A propósito, se puede recordar el reproche que le hacía Marshall Sahlins a Evans-Pritchard por creer que los isleños de los Mares del Sur carecían de historia, cuando tan sólo les faltaba el registro textual de sus actos. ${ }^{2} \mathrm{~A}$ la insularidad cubana le falta el continuum de su devenir cultural y por eso su experiencia de la historia es ajena al metarrelato de la identidad.

${ }^{1}$ Louis Dumont, Homo aequalis, 1982, Madrid, Taurus, p. 14.

${ }^{2}$ Marshall Sahlins, Islas de historia, 1988, Barcelona, Gedisa, p. 18. 
Pero abundan los testimonios del acto histórico en Cuba, a la manera de la muerte del capitán Cook imaginada por los salvajes de las islas Sandwich como un sacrificio divino. Es decir, la trayectoria de la cultura cubana no dispone de metatexto racional, pero sí de los signos e imágenes que fragmentan su tiempo. En este sentido, la propuesta de Sahlins de concebir la historia insular a través de una "mitopraxis" sucesiva es perfectamente aplicable al caso cubano. ${ }^{3}$

Sin embargo, en la intelectualidad cubana siempre ha habido mentes que dudan de la definición nacional de la isla. José Antonio Saco, Enrique José Varona, Fernando Ortiz, Jorge Mañach y Virgilio Piñera, alguna vez pensaron que Cuba no era una nación. Frente a esta desconfianza se coloca el credo de los que celebran la epifanía del ser nacional: Félix Varela, José de la Luz y Caballero, José Martí, José Lezama Lima y Cintio Vitier. Ésta es la tradición que ha presentado las pruebas ontológicas de la existencia insular. $Y$ en uno de sus textos primordiales, Lo cubano en la poesía, encontramos que tanto el alejamiento del cuerpo insular como su penetración son pautas expresivas de la criatura cubana. ${ }^{4}$ De modo que divisar la isla desde lejos es uno de los ejes históricos de la cultura en Cuba, mientras el otro es lo que

\footnotetext{
${ }^{3}$ Ibid, p. 118.

${ }^{4}$ Cintio Vitier, Lo cubano en la poesía, 1958, La Habana, Universidad Central de las Villas, p. 486.
}

Guillermo Cabrera Infante hallamado "el exilio interno".

La escasa densidad histórica de $\mathrm{Cu}$ ba, en vez de generar una cultura anclada en el presente, ha desatado una perpetua gravitación hacia el futuro. Desde sus orígenes, en el siglo XIX, el discurso cubano ha revelado una intensa voluntad de sublimación utópica. ${ }^{6}$ Se trata, en palabras de José Lezama Lima, de la génesis poética y moral de una "tradición por futuridad". Los cubanos inventan una historia de actos intangibles, cuya verificación en el tiempo funciona unas veces como profecía y otras como deseo. De nuevo, a través de la experiencia cubana, la insularidad sirve de espacio mínimo para el imaginario utópico. Las islas, al decir de Michel Butor, son lugares de consenso y espera: sus habitantes viven y mueren con la certeza de que la historia volverá a originarse allí y con ellos. ${ }^{7}$ Es ésta la sensación adánica de los insulares: creen que están antes o después del tiempo. El horror vacui de Pascal, la soledad de los espacios infinitos, se teme lo mismo desde un oasis en el desierto que desde una isla en el mar. Por eso la cultura cubana, para tocar el tiempo y huir del espejismo insular, ha recurrido a lejanías e in-

${ }^{5}$ Guillermo Cabrera Infante, Mea Cuba, 1993, México, Vuelta, p. 375-82.

${ }^{6}$ Rafael Rojas, Viaje a la semilla. Instituciones de la antimodernidad cubana, Postmodern Notes, 1993, Miami, Verbum, p. 15-9.

${ }^{7}$ Michel Butor, Repertorio, 1970, Barcelona, Seix Barral, p. 87. 
NOTAS

mersiones, se aleja fuera y dentro del país. Son las dos formas de asumir los bordes de la isla.

\section{Lejanías}

Cada desaparición de una cultura en otra a lo largo de la historia cubana ha provocado su propio exilio. Las primeras señales de la nacionalidad en el discurso criollo de los siglos XVII y XVIII remiten siempre a una mirada exterior. La escritura epiciforme del Espejo de paciencia (1608) enlaza el origen del texto cubano con el noticiario sobre rarezas de Cuba que aparece en las crónicas de los viajeros. Silvestre de Balboa registra en su narración una "historia exótica", es decir, cuenta un suceso que resulta ajeno a su racionalidad. La "divina paciencia" de Fray Juan de las Cabezas y Altamirano y la "milagrosa victoria" del capitán Gregorio Ramos sólo podían concurrir en la "más famosa" de las islas. ${ }^{8}$ Este extrañamiento en el espacio y la trama identifica a Balboa con la visión de algunos viajeros de los siglos XVI y XVII, como A. O. Esquemeling y Martín Fernández de Enciso. De manera que aquel canario, vecino de Puerto Príncipe, no escribía desde Cuba sobre la prisión de un obispo en Manzanillo, sino desde el exterior.

${ }^{8}$ Silvestre de Balboay Troya de Quesada, Espejo de paciencia. Santiago Pita, El Príncipe Jardinero y Fingido Cloridano, 1975, La Habana, Arte y Literatura, p: 49-56.
El siguiente testimonio textual de la cultura cubana reincide en esta exterioridad. La comedia bucólico-portuaria de Santiago Pita, en 1730, terminaba con unos versos contradictorios: "Y El príncipe jardinero, /de un ingenio de La Habana/ hecha en Sevilla, da fin". "Era este texto habanero o sevillano? Al parecer ni lo uno ni lo otro, sino todo lo contrario: era la refundición de una obra teatral del florentino Giacinto Andrea Cicognini. Antonio Bachiller y Morales afirmó que "toda la Habana se sabía escenas completas del drama". Vemos aquí el origen del confuso imaginario criollo: la memoria habanera reproducía visiones que proyectaban su espacio en textos ajenos y distantes. La mirada exterior configuraba una imagen propia que servía luego como principio de alteridad frente a otros mundos.

La historiografía criolla del siglo XVIII, con Pedro Agustín Morell de Santa Cruz, José Martín Félix de Arrate, Nicolás Joseph de Ribera y José de Urrutia, abre otra dimensión de la exterioridad cultural en Cuba. El inventario de rarezas, ésta vez, desplaza la referencia al mito clásico por los códigos de la razón ilustrada. Arrate, por ejemplo, impugna la leyenda de Gea y Anteo para negar que los criollos requieran siempre de la protección de España en el logrode sus fines. ${ }^{10} \mathrm{Se}$ pasa del asombro a la curiosidad y de la

${ }^{9} \mathrm{Ibid}$, p. 221.

${ }^{10}$ Carmen Almodóvar Muñoz, Antología crítica de la historiografía cubana, 1986, La Habana, Pueblo y Educación, t. I, p. 139. 
grandilocuencia a la descripción, según el modelo de la Historia Natural del Conde de Buffon. En lugar de un escenario imaginado de fantasías marinas y honorables proezas aparece el paisaje observado del mundo físico y moral. Compárese, para este fin, el retrato que hiciera Silvestre de Balboa de las virtudes de fray Juan de las Cabezas y Altamirano con el que ofrece Morell de Santa Cruz del fray Julián Garcés. ${ }^{11}$

La mirada exterior que funda la alteridad criolla ya no es la del viajero, sino la del naturalista. La clasificación del entorno natural y social del Nuevo Mundo era una de las prioridades dè la burocracia borbónica. Los jardines botánicos, las expediciones científicas y los laboratorios universitarios fueron prácticas del saber ilustrado que ejercitaron una imagen del espacio americano. De acuerdo con ella los criollos se autocontemplaban sin dejar de sentir la otredad que se abría paso entre las élites de ultramar. Por eso era como si el discurso criollo tuviera dos ojos: uno propio para observarse a sí mismo y otro ajeno para percibir su paisaje. Esto explica que Arrate y Ribera pudieran exaltar a los notables habaneros por encima de sus padres peninsulares $y$, a la vez, admitir que loś habitantes y condiciones de la isla no llenaban el objeto de su Metrópoli. ${ }^{12}$

Con el advenimiento del siglo XIX se da el tránsito del discurso de la alteridad criolla al de la identidad cubana. Justo aquí la exterioridad se vuelve

${ }^{11}$ Ibid, p. 115-8.

${ }^{12}$ Ibid, p. 144. exilio y la extrañeza lejanía. Al reconocerse plenamente en su ámbito cultural y natural, el cubano adquiere la capacidad de abandonar su espacio. La conciencia de sí le llega acompañada del deseo o la necesidad de trascender su territorio. Nace entonces la cultura nacional sin una soberanía estatal y esto provoca que gran parte de la expresión cubana del siglo XIX esté asociada al destierro. Pero, en todo caso, sería una exageración imaginar todos los signos intelectuales de la $\mathrm{Cu}$ ba colonial dentro del enfrentamiento al dominio español. Como en casi todas las culturas nacionales, en la cubana del siglo pasado había zonas de neutralidad que no gravitaban hacia la fundación política de un nuevo Estado.

De la generación ilustrada que vivió el tránsito de la cultura criolla a la nacional sólo Ventura Pascual Ferrer repartió sus días entre La Habana, Madrid y Cartagena de Indias. Francisco de Arango y Parreño, José Agustín Caballero, Tomás Romay, Juan Bernardo O'Gavan y Manuel de Zequeira pasaron su madurez intelectual en $\mathrm{Cu}$ ba. En cambio, las cuatro figuras cardinales de la generación siguiente, Félix Varela, José Antonio Saco, José María Heredia y. Domingo del Monte, produjeron lo fundamental de sus obras en el exilio. Es cierto que el espacio público de la cultura cubana fue siempre conservado en la isla por los que permanecieron allí; esto es, por José de la Luz y Caballero, los hermanos González del Valle, Ignacio Valdés Machuca, Francisco Iturrondo, Plácido, el presbítero Francisco Ruiz y Manuel 
NOTAS

Costales, entre otros. Pero es innegable que el aporte esencial de la intelectualidad cubana a mediados del siglo pasado se verificó en el destierro.

Elgran poeta romántico José María Heredia vivió una suerte de frenesí republicano en México, de 1825 a 1836. Allí coincidió con su compatriota desterrado, Antonio José Valdés, autor del primer texto moderno sobre la historia nacional: Historia de la isla de Cuba y en especial de la Habana. La desilusión política y la nostalgia por Cuba lo impulsaron a escribir una carta al Capitán General de la Isla, Miguel Tacón, en la que se retractaba de sus ideas separatistas. Gracias a este gesto, que lo condenó al ostracismo por sus contemporáneos, pudo visitar la isla antes de morir en México tres años después. Domingo del Monte, el crítico literario y promotor cultural más importante de la primera mitad del siglo XIX cubano, rehusó encontrarse con su íntimo amigo Heredia durante la estancia de este último en La Habana.Pero en ese momento no sospechaba que diez años después se vería en el caso de pedirle al Gobernador de $\mathrm{Cu}$ ba, Leopoldo O'Donnell, que le permitiera regresar a su país. La petición le fue negada y Del Monte tuvo que vivir el resto de sus días en Europa.

El padre Félix Varela salió de Cuba en 1821 y jamás regresó. Si para la cultura insular fue el primero de los cubanos, entonces para la política fue el primero de los exiliados. En Nueva York, donde pasó la mayor parte de su vida, no sólo se dedicó a la propaganda pública en favor de la independencia de Cuba, sino que se integró plenamente al medio católico norteamericano. Fue profesor de teología del Seminario de Santa María de Baltimore y en 1837 llegó a ser vicario general de Nueva York. José Antonio Saco, su discípulo y heredero de la cátedra de filosofía del Seminario de San Carlos de la Habana, fue deportado en 1834. Su abarcadora y fecunda actividad intelectual transcurrió sobre todo en Europa y sólo a finales de 1860 regresó por breve tiempo a La Habana, con motivo del título de profesor emérito que le concedió la Real Academia de Ciencias Médicas, Físicas y Naturales de esa ciudad.

Con Heredia en México, Del Monte en Madrid, Saco en Londres y Varela en Nueva York, el exilio intelectual cubano estaba disperso. Al parecer, ésta ha sido otra constante de la historia insular: el éxodo cultural se reparte entre varias comunidades. Fue ese rasgo el que hizo hablar a Calvert Casey, en la década del 60, de una "diáspora cubana". ${ }^{13}$ Pero tanto en el exilio revolucionario, como en el colonial, el espacio norteamericano ha sido el principal cónclave de debate sobre el destino de Cuba. En el El Mensajero Semanal, periódico cubano publicado en Nueva York de 1828 a 1831, José Antonio Saco sostuvo una brillante polémica con el polígrafo español Ramón de la Sagra, en la que apareció lá primera defensa pública de la cultura desterrada. La Sagra, que representaba la razón

${ }^{13}$ Guillermo Cabrera Infante, op cit., p. 375 . 
NOTAS

colonial, atacó a José María Heredia, primer poeta de América y autor del célebre Himno del Desterrado, y a Félix Varela, editor de la publicación separatista El Habanero. La respuesta de Saco fue entonces el testimonio de que los signos esenciales de la cultura cubana se articulaban en el exilio.

En 1839, cuando Heredia moría desgarrado por la distancia, se publicó en La Habana la gran novela cubana del siglo XIX: Cecilia Valdés; o, La Loma del Angel. Su autor, el pinareño Cirilo Villaverde, era sospechoso de ideología independentista, aunque en realidad simpatizaba con el anexionismo norteamericano. Por conspiraciones dirigidas a este fin fue encarcelado en 1848 , pero al año siguiente consiguió huir y emigró a los Estados Unidos. Vivió en Nueva York hasta su muerte y allí se convirtió en una figura clave de la opinión cubana del exilio. Villaverde abrió en el destierro un espacio público para las letras insulares, sólo comparable al que logró en España la poetisa camagüeyana Gertrudis Gómez de Avellaneda. De La Peregrina, como la retrataba su propio pseudónimo, se ha dicho con razón que tanto exilio la hizo extranjera y murió espanola. Es curioso que, a pesar de que en versos llamara a Cuba "patria feliz" y "edén querido", el último Diccionario de la Literatura Cubana (Academia de Ciencias, La Habana, 1980-84) se refiera a su país como "isla natal". Pero bueno, hablamos de un diccionario de las letras cubanas donde no aparecen los nombres de Roberto Agramonte, Herminio Portell Vilá, Leví Marrero,
Gastón Baquero, Guillermo Cabrera Infante y Severo Sarduy. Estos son los nuevos desterrados de la cultura insular.

Los treinta años de génesis de la independencia, de 1868 a 1898, fueron una época de últimos regresos, estancias clandestinas y nuevas fugas. En 1870 , el poeta Juan Clemente Zenea se internó secretamente en la isla para negociar con los insurrectos una paz que tuviera como condición el reconocimiento de la autonomía cubana. El gobierno español, supuesto beneficiario de su misión, lo encarceló ocho meses en la fortaleza de la Cabaña y luego dispuso su fusilamiento. La República en Armas tampoco confió en sus credenciales separatistas y el poeta bayamés quedó rechazado por las dos lealtades políticas en conflicto. Algunos de los mejores poemas de Zenea se publicaron en Nueva York, hacia 1858 , dentro de una antología colectiva titulada El laúd del desterrado, que incluyó a otros escritores cubanos en el exilio como Leopoldo Turla, Miguel Teurbe Tolón, Pedro Angel Castellón, José Agustín Quintero y Pedro Santacilia, quien luego se convertiría en el secretario particular del presidente mexicano Benito Juárez.

Zenea es el caso extremo de la soledad del intelectual en Cuba, ya que fue un desterrado de su país y de las dos culturas que se disputaban la soberanía insular. Por eso su figura se ha convertido en una metáfora del desencuentro secular entre los intelectuales y el poder en Cuba. Desde José Martí hasta Abilio Estevez, pasando por Cintio Vitier y Guillermo Cabrera Infante, 
NOTAS

la memoria de Zenea ha sido siempre un foco de complicidad gremial para los escritores cubanos. Pero la primera reivindicación de este poeta atrapado por la intolerancia política se debe al ensayo Vida y escritos de Juan Clemente Zenea, publicado en París en 1901. Su autor, Enrique Piñeyro, el crítico literario más importante de finales de siglo, había regresado a Cuba, como Manuel de la Cruz, Manuel Sanguily, José Martí y otros intelectuales separatistas, tras la amnistía decretada por el Pacto del Zanjón. Pero al año siguiente ya editaba sus célebres Estudios y conferencias de historia y literatura en Nueva York y meses después se instalaba definitivamente en París. Allí murió en 1911, después de haber atiborrado las editoriales francesas de bibliografía cubana. Sus penetrantes estudios sobre José María Heredia, Gertrudis Gómez de Avellaneda y Juan

76 Clemente Zenea constituyen, desde el exilio, la primera aproximación reflexiva a la gran poesía cubana del destierro.

José Martí, fundador de otra escritura hispanoamericana y máxima referencia de la historia de Cuba, salió de su país a $\operatorname{los} 17$ años. En toda su existencia adulta Martí sólo vivió un año y quince días en Cuba: del 31 de agosto de 1878 al 15 de septiembre de 1879. En enero de 1877. había pasado clandestino por la Habana y entre abril y mayo de 1895 , víspera de su caída-suicidio en combate, vivió alzado en los montes del sureste de la isla. De modo que toda la obra política y poética de Martí, tan decisiva para la historia y la cultura cubanas, fue concebida en el exilio.
Pero además, el propio Martí, considerado después por el Estado republicano como el Apóstol de la Patria, formó su partido independentista con los emigrados cubanos de Tampa y Cayo Hueso. $\mathrm{Y}$ al hablar de los sectores sociales de Cuba que apoyaban la ruptura con España se refería siempre al "pueblo de mente contemporánea y superior capacidad, sazonado en la gloria de la guerra y la disciplina del destierro". ${ }^{14}$ De modo que Martí se basó en dos experiencias históricas para organizar su movimiento político: la guerra de los diez años (1868-1878) y el exilio.

Martí tuvo la suerte de morir en $\mathrm{Cu}-$ ba, pero otros fundadores de la nación insular desaparecieron en la soledad del destierro. Antonio José Valdés y José María Heredia murieron en la Ciudad de México, Varela en San Agustín (La Florida), Saco en Barcelona, Del Monte y la Avellaneda en Madrid, Villaverde y De la Cruz en Nueva York, Enrique Piñeyro y Francisco de Frías y Jacott (Conde de Pozos Dulces) en París. Si bien no toda, una parte sustancial de la cultura cubana había muerto en el exilio. Por eso uno de los actos iniciales de la República de 1902 fue la repatriación de los restos de los intelectuales desterrados. Era, a fin de cuentas, un gesto indispensable para la legitimación del nuevo régimen: recuperar los cadáveres de la cultura que había inventado una nacionalidad que luego se convirtió en Estado. Así fue

${ }^{14}$ José Martí; "Ciegos y Desleales" en Obras Escogidas, 1992, La Habana, Editorial de Ciencias Sociales, t. III, p. 171. 
como, sin conciencia, Varela y Del Monte regresaron a Cuba. Pero los restos de Heredia se perdieron en México y los otros siguen en el lugar que les asignó el exilio.

\section{Regresos}

Las tres primeras décadas de la historia republicana fueron un lapso de recuperación cultural del espacio. La nueva generación intelectual se concentró en el diseño de las instituciones espirituales del Estado independiente. Francisco Figueras, Jesús Castellanos, los hermanos Lles, Joaquín Llaverías, Miguel de Carrión, Carlos Loveira, Ramiro Guerra, Fernando Ortiz, trabajaron la mayor parte del tiempo en Cuba. Su entusiasmo inicial por el orden soberanose nutría del aliento delos intelectuales predecesores que, como Enrique José Varona, Manuel Sanguily, Domingo Figarola-Caneda y Carlos M. Trelles, transitaban de la Colonia a la República. Este retorno de la intelectualidad al espacio nacional correspondió a la época de mayores índices de inmigración europea, sobre todo gallega y asturiana, en la isla. Así, el país se iniciaba en la vida independiente bajo un clima de gravitación cultural hacia su territorio.

El testimonio más claro del reencuentro republicano entre los intelectuales y su paisaje fue la generación de 1920. Se puede afirmar con propiedad que en esta década culmina la génesis de la cultura nacional. Los criollos del siglo XIX se habían convertido en cubanos sin la certeza histórica de su propia transformación. Esta autoconciencia le perteneció a sus hijos y por eso veinte años después de fundada la República surge el discurso de la historia nacional. Pero no sólo el autocercioramiento del devenir insular verifica, en los años 20, la expresión de la nacionalidad en la cultura, sino el enlace de muchos lenguajes y discursos en una sóla escritura de la identidad nacional. En estos años la intelectualidad deja de ser un gremio dominado por filósofos, poetas, narradores y críticos; es decir, una "república de las letras", para convertirse en una corporación que involucra a músicos, bailarines, coreógrafos, pintores, escultores, arquitectos, académicos y periodistas. Habrá que esperar hasta el grupo Nuestro Tiempo, en los años 50, para que la sociabilidad de los intelectuales incorpore a dramaturgos y cineastas. Pero es indiscutible que a finales de los 20 la articulación de una "retórica vanguardista" por parte de autoridades de la cultura, como el Grupo Minorista y la Revista de Avance, favoreció la entrada de la pintura de Victor Manuel y Carlos Enríquez y la música de Amadeo Roldán y Alejandro García Caturla en esta poética generacional.

La coherencia cultural del movimiento artístico en los años 20 posibilitó, en gran medida, la pluralidad ideológica de los intelectuales antimachadistas que se involucraron en la Revolución de los años 30 . Esto explica, de alguna manera, que el exilio en estas décadas no haya sido provocado tanto por principios doctrinales oestéticos como por coyunturas políticas. La dictadura de Machado 
NOTAS

desterró a algunos intelectuales comunistas, como Julio Antonio Mella, Martín Casanovas y Juan Marinello, pero el espacio nacional para la creación y circulación de la cultura se conservó. Casanovas era editor de la Revista de Avance y su encarcelamiento y salida del país no afectaron en nada la publicación de aquel medio primordial de la intelectualidad cubana. Estos exilios, además de breves, nunca provocaron el traslado del espacio público insular al exterior. Los pintores, poetas, músicos y narradores de la década del 30 emigraron buscando el desarrollo o promoción de sus obras en el extranjero y siempre regresaron a confirmar su lenguaje ante la opinión cubana.

La apertura del espacio público, iniciada en los años 20 , no hizo más que acentuarse en las tres décadas posteriores. Un momento clave de este ensanchamiento cultural fue el diseño democrático de la Constitución de 1940. Los mecanismos reproductivos de la expresión intelectual continuaron desarrollándose por medio de institutos estatales o privados, de manera que llegó a ser lo suficientemente sólido el andamiaje institucional de la cultura cubana como para que el golpe militar del 10 de marzo de 1952, a pesar de interrumpir la constitucionalidad del país, no desajustara las artes y las letras republicanas. Esta fijación de la cultura insular a su territorio en la época republicana impidió el establecimiento de ciertas sedes de cultura emigrada, como las que habían generado los tiempos coloniales y luego se reeditaran durante la Revolución socialista.
En los primeros años de la dictadura batistiana el esquema de la emigración cultural fue muy parecido al de la época machadista. Es decir, se dieron destierros aislados por motivos políticos, como el del importante poeta comunista Nicolás Guillén, que no llegaban a constituir núcleos fuertes de cultura cubana en el extranjero. Los músicos Harold Gramatges, Juan Blanco, Argelieres León, los cineastas Tomás Gutiérrez Alea, Julio García Espinoza, Santiago Alvarez y los escritores Lisandro Otero y Fayad Jamís, que habían fundado la Sociedad Cultural Nuestro Tiempo, viajaron a Europa en la primera mitad de los 50 para completar su formación académica. Pero la Sociedad y su revista siguieron funcionando hasta después del triunfo de la Revolución y estos intelectuales regresaron a pesar de la atmósfera insurreccional que se expandía en la isla. Fue a partir de 1957, cuando arreció la represión política, que el éxodo intelectual aumenta y los márgenes de la cultura se estrechan considerablemente. En ese año la revista Ciclón deja de aparecer y Roberto Fernández Retamar, Pablo Armando Fernández, José Triana, Antón Arrufat, José A. Baragaño, Jaime Sarusky, Ambrosio Fornet, Heberto Padilla, Edmundo Desnoes, junto con otros intelectuales de su generación, ya son parte de un exilio que culminará en menos de dos años.

Quizá las únicas excepciones dentro de esta ausencia de exilio cultural en la época republicana hayan sido Alejo Carpentier, Wifredo Lam y Virgilio Piñera. Carpentier salió de la $\mathrm{Ha}$ - 
bana con la documentación personal del poeta surrealista Robert Desnoes a finales de los años 20 . Residió en París por casi diez años y luego de una breve estancia en Cuba, a mediados de los 40 , se instala en Venezuela. Cuando regresó a la Habana, después del triunfo de la Revolución de 1959, Carpentier había escrito y publicado una parte esencial de su valiosa narrativa en el extranjero. Pero en 30 años sus trabajos nunca dejaron de aparecer en publicaciones de la isla, como la Revista de Avance, Social, Carteles y Orígenes. Un caso similar, por sus comunes inspiraciones francesas y antillanas, fue el del gran pintor Wifredo Lam. A quien, ya en 1934, lo vemos discutiendo sus dibujos con Pablo Picasso en el café Aux Deux Magots de París. Luego de la ocupación de Francia por los nazis, Lam pasa a Marsella y de ahí inicia su anhelado periplo antillano: Martinica, Santo Domingo, Haití, Cuba. A principios de los 50 vuelve a embarcarse hacia París y no regresa hasta 1958, cuando la violencia política que encontró le hizo exclamar la célebre frase: "iaquí han soltado los demonios!". 15

Después de dirigir la revista Poeta (1942-43) y colaborar en la fundación de Espuela de Plata, Clavileño y Nadie Parecía, Virgilio Piñera se trasladó a Buenos Aires. Allí vivió catorce años y publicó su importante novela La carne de René y la antología narrativa Cuentos Fríos. Pero, desde Argentina, la

${ }^{15}$ Guillermo Cabrera Infante, op. cit., p. 205. presencia de Piñera en la vida cultural cubana fue tan intensa que se hace difícil definir su caso como exilio. La inmersión de este intelectual en el medio literario argentino, evidenciada por sus publicaciones en Sur, Hoy, Realidad, Mundo Argentino y Anales de Buenos Aires, no le impidió conservar su enlace con la escritura de la isla. Prueba de ello son sus poemas, cuentos y reseñas en Orígenes (1944-55) y su intervención directa en el proyecto y obra de la revista Ciclón (1955-57). Virgilio Piñera, por su irreverencia y causticidad frente a las autoridades de la cultura cubana, pudo haber sido un exiliado, sin embargo con los años demostró que una vida al margen de la intelectualidad insular le resultaba imposible.

El triunfo de la Revolución, en enero de 1959, fue otra vez una circunstancia de regresos. Las cuatro generaciones de intelectuales republicanos se reunieron para celebrar el acontecimiento y ofrecer sus servicios a la cultura del nuevo Estado. Pero muy pronto la radicalización socialista del orden revolucionario y el torpe diseño de la política intelectual provocaron la segunda gran ola de éxodo ideológico y cultural de la historia de Cuba. Primero emigraron los intelectuales ligados a la cultura política republicana, que rechazaban la orientación comunista del nuevo sistema: Jorge Mañach, Roberto Agramonte, Humberto Piñera Llera, Leví Marrero, Félix Lizaso, Francisco Ichaso, Gastón Baquero, Lidya Cabrera...y más tarde Enrique Labrador Ruiz. Luego el exilio se con- 


\section{NOTAS}

virtió en un mecanismo de deserción y escape para los escritores que intentaban construir un discurso disidente dentro de Cuba, o bien para los que vivían acosados por la policía política. Así salieron Guillermo Cabrera Infante, Carlos Franqui, Juan Arcocha, Calvert Casey, José Triana, Reinaldo Arenas, Edmundo Desnoes, Antonio Benítez Rojo, César Leante, Heberto Padilla... $y$, en fechas recientes, Manuel Díaz Martínez y Jesús Díaz. Otra variante de éxodo fue la de intelectuales que, como Eugenio Florit o Severo Sarduy, se encontraban en el extranjero al triunfo de la Revolución y decidieron no regresar. De manera que, con independencia del año de salida, se puede hablar de dos grandes arquetipos del exilio cultural en la Revolución: el de los intelectuales republicanos o "tradicionales" que no asimilaron el nuevo orden - casos de Jorge Mañach y 80 Enrique Labrador Ruiz - y el de los revolucionarios u "orgánicos" que desertaron o simplemente se les hizo insostenible una postura crítica dentro de Cuba, como Guillermo Cabrera Infante y Jesús Díaz.

En la primera mitad de los años 60, la intelectualidad cubana se identificó con un proyecto político y moral renovador que inducía a la experimentación discursiva. Se vivió por esos años cierta convergencia de postulados vanguardistas en la cultura y la política, que recuerdan al movimiento intelectual de la década de los veinte. Pero pronto aparecieron las primeras señales de una ortodoxia estética que propició la censura de la película $P M$, el cierre de Lunes de Revolución, la vigilancia y castigo de los escritores homosexuales y el caso Padilla. Esta reacción contra la propia libertad expresiva que generó el proceso revolucionario, fue el fundamento del segundo exilio intelectual. Veinte años después, a mediados de los 80 , sucedió algo muy parecido que condujo a una nueva experiencia de emigración artística. El reajuste institucional provocado por la Rectificación y la vuelta al paradigma guevarista flexibilizaron la política cultural del Estado cubano. Fue ese el momento en que las artes plásticas, el teatro y el pensamiento crítico alcanzaron un auge inusual dentro de la estética revolucionaria. Entonces sobrevino la clausura de los espacios públicos y la neutralización del movimiento intelectual de los 80 . Así se dio el tercer exilio cultural de la historia revolucionaria: una suerte de éxodo fomentado por el Estado para garantizar a la vez el silenciamiento de la opinión crítica y el flujo de ingresos que reportaba el mercado del arte en el exterior. Por eso Arturo Cuenca, intelectual protagónico de la generación de los 80 que reside en Nueva York, habló de un exilio de baja intensidad: y Osvaldo Sánchez, poeta, narrador y crítico que vive en México, completando la idea, se refirió con ingenio al exilio de terciopelo.

De manera que la época revolucionaria ha sido, después de la colonial, la que más éxodo de intelectuales ha desatado en la historia de Cuba. Pero, al igual que en el siglo XIX, el exilio intelectual de la Revolución no pudo 
expatriar toda la cultura cubana. En la isla quedaron Fernando Ortiz, José María Chacón y Calvo, Elías Entralgo, Medardo Vitier, Emilio Roig de Leuchsenring, Ramiro Guerra, José Lezama Lima, Cintio Vitier, Eliseo Diego, Virgilio Piñera, José Rodríguez Feo, Manuel Moreno Fraginals, Julio Le Riverend..., más casi todos los pintores, músicos, dramaturgos y cineastas. El verdadero dilema del exilio no es que trasplanta una cultura en otro espacio sino que reparte una misma cultura entre dos espacios hostiles. De ahí que, para esa encrucijada, no haya otra salida que el reencuentro de las dos tradiciones en su propia historia.

\section{Inmersiones}

La cultura cubana ha experimentado momentos de compulsiva politización: los años de 1820 por el contagio de la independencia hispanoamericana; los de 1830 con la oposición al régimen de facultades omnímodas del general Miguel Tacón; los 30 años del movimiento separatista (1868-1898), la dictadura de Machado y la Revolución de 1933; la de Batista y la Revolución de 1959; la década del 60 con la fe en el "hombre nuevo" y la culpa por el "pecado original" de los intelectuales que no participaron en la guerra y, finalmente, la segunda mitad de los 80 , cuando comienza la búsqueda de un discurso reformista. Estas politizaciones de la cultura, que involucran a las mayorías culturales, se han dado acompa- ñadas de dos formas de marginalidad intelectual: el exilio y el insilio, el destierro y el entierro, el escape extramuros y el enclaustramiento, el éxodo y la fuga interior.

Pero estas reacciones no sólo están asociadas al tiempo político sino al cultural; es decir, los escapes hacia afuera y adentro responden a ciertos grados de apertura del espacio público y de separación entre las instituciones culturales y el Estado. La República (1902-1959), qué duda cabe, ha sido la época de mayor libertad de expresión en toda la historia de Cuba. De manera ostensible, ese fue el período de menos exilio intelectual y más inmersión reproductiva en la cultura cubana. Esto indica que la fijeza territorial de los intelectuales depende de los márgenes de neutralidad y crítica que posee la cultura frente a la política. En otras palabras, el intelectual requiere de la posibilidad de intervenir o no en la cosa pública para reconocerse en su espacio, ya que la definición nacional que alcanza por medio de la cultura no está ligada a la forma inmediata del Estado. Claro, hablamos aquí de los intelectuales que asumen sus funciones desde la perspectiva de una identidad nacional alcanzada.

En la cultura colonial del siglo XIX no se puede hablar de formación del espacio público hasta 1878. Los primeros signos de la identidad cubana subsistieron por varias décadas sin medios ni instituciones para su expresión. Esta insuficiencia institucional de lo público generó una serie de reproducciones marginales de la cultura insu- 


\section{NOTAS}

lar. Una de ellas, quizá la de mayor continuidad en la historia de Cuba, ha sido la tertulia casera. Así como los palacetes habaneros de los Aldama y los Alfonso fueron círculos elitistas de sociabilidad política, la casa de Domingo del Monte, a partir de 1836 y hasta su huída a Filadelfia en 1842, se convirtió en un centro alternativo de difusión cultural. Por esos años Ignacio Valdés Machuca creó en su casa una academia literaria donde Plácido, Manzano, Francisco Pobeda y Armenteros, leyeron sus primeros versos. La compensación cubana del déficit de lo público en lo doméstico ha sobrevivido desde entonces a través de los González del Valle, los Zambrana, los Borrero, los Loynaz del Castillo, el curso délfico de Lezama, el bungalow de Virgilio Piñera en Guanabo... Tres experiencias recientes confirman la trasmisión en la longue durée de esta estructura marginal para el reparto de la cultura: la academia postestructuralista que organizó el grupo Paideia en el departamento del joven intelectual Ernesto Hernández Busto, las representaciones de teatro extraverbal en la sala del dramaturgo Victor Varela y la tertulia literaria que todavía hoy funciona en la azotea de la poetisa Reina María Rodríguez.

La insularidad de la cultura cubana ha producido también un tipo de intelectual que rechaza el viaje, una suerte de weltbürger estático. Se trata de un personaje que huye de la superficie pública de la isla y logra, por medio de raras lecturas e imaginación desmesurada, un saber tan exacto como fic- ticio sobre el mundo exterior. El primer ejemplar conocido de esta especie en la cultura cubana es el poeta Julián del Casal. Ramón Meza cuenta que, a finales de los años 1880, Casal, obsesionado por la lectura de los decadentes franceses y, sobre todo, de Joris Karl Huysmans, vivía en un pequeño cuarto, en la esquina de Habana y O'Relly, detrás del periódico La Habana Elegante, repleto de biombos, divanes, jarrones, abanicos, budas y todo tipo de japonerías. ${ }^{16}$ Allí construía una imagen exótica de las civilizaciones orientales y en ese paisaje instalaba su trama poética. Las otras tres grandes referencias espaciales de la poesía de Casal eran la Grecia clásica, España y Francia como lo ilustran sus versos de Bocetos Antiguos, Cromos Españoles y Nieve. Pero se sabe que el único viaje que emprendió a Europa, con la finalidad de conocer París y las otras ciudades de sus ensueños, terminó en menos de tres meses y no pasó de Madrid.

Durante la República, este arquetipo del intelectual de vasta cultura y traslado difícil se reprodujo en pequeña escala. En casi todos los pueblos cubanos ha existido un sabio que, a pesar de no haber salido más allá de la comarca vecina, cumple funciones de enciclopedia ambulante. Estos son los letrados anónimos, pero entre los intelectuales reconocidos el modelo del weltbürger estático no hizo más que acentuarse. Fernando Lles, apenas

${ }^{16}$ Julián del Casal, Selección de poesías, 1931, La Habana, Colección de Libros Cubanos, p. XXXVIII. 
sin salir de la ciudad de Matanzas, concibió, en las primeras décadas republicanas, los más lúcidos ensayos filosóficos jamás escritos en Cuba: $L a$ higuera de Timón, La sombra de Heráclito y La escudilla de Diógenes. El alucinado pintor Fidelio Ponce, creador de unas fantasmales escenas ocrevioláceas, nunca fue a Nueva York o París y ni siquiera visitó museos en Cuba. Mientras uno de sus cuadros se exponía en el Delphic Studios de Manhattan, el pintor trabajaba en un mural al óleo en la escuela municipal José Miguel Gómez. A veces sus amigos le perdían el rastro y se aseguraba que las depresiones lo llevaban a "refugiarse en el interior del país". Así, Ponce se aislaba en la isla, repetía la insularidad de su cultura al hundirse y desaparecer, para luego ganar la superficie enmascarado, como una de sus cabezas evanescentes. Al regresar de esos exilios internos a su caseta del sanatorio La Esperanza, el pintor podía describir Marsella o Berlín y hablar de sus correrías con Franz Halz, Renoir, Corot y Toulouse-Lautrec. ${ }^{17}$

Pero el caso paradigmático de esta hiperinsularidad intelectual es el del increible poeta José Lezama Lima. Ese inventor de otra lengua, que construyó todo un sistema poético a partir de inspiraciones ancestrales de la cultura europea y registró en su escritura las más caprichosas referencias clásicas y medioevales, raras veces salía de su

${ }^{17}$ Lolo de la Torriente, Estudios de las artes plásticas en Cuba, 1954, La Habana, Ucar y García, p. 168-70. angosta casa habanera. En una ocasión otro gran poeta cubano, Gastón Baquero, lo invitó a la ciudad de México, pero Lezama sólo llegó hasta su escala en Jamaica. Fue su único viaje $y$, menos que eso, fue una travesía trunca a la que el poeta dedicó estos versos reveladores de su imaginativa quietud: "Para llegar a Montego Bay,/el oscuro furor adolescente escondía sus flechas,/ y no el retiramiento de participar en la ausencia..." A partir de la metamorfosis de esta ausencia física en imagen presente, Lezama armó su visión de la historia insular y conforme a ella se articuló el discurso del grupo Orígenes. Fue esa generación intelectual de los años 40 la única que, a diferencia del grupo Minorista en los 20 y Nuestro Tiempo en los 50, no formuló su poética dentro de enunciados políticos. Orígenes aspiró a una incidencia en la historia desde la cultura y esa estrategia oblicua, marginal, salvó a sus intelectuales del destierro pero los condenó a la errancia interior.

Dos formas de la cultura insular, una de lejanías y otra de inmersiones, aun enfrentan a los intelectuales cubanos. Pero sólo encadenadas configuran la expresión de la identidad. Ambas rehuyen la superficie pública y gravitan hacia el refugio que les ofrecen los márgenes del éxodo y el aislamiento. Tal vez haya que convocarlas algún día al espacio más visible de la isla, para reintegrar de una vez y por todas el cuerpo de la cultura cubana. Eso sería, como pensaba Martí, el saber de una nación expresado en pocas palabras. 